\title{
Transient severe distributive shock due to early dumping syndrome: a case report
}

\author{
Jun Takeshita ${ }^{* *}$, Kei Nishiyama², Satoru Beppu², Nozomu Sasahashi ${ }^{2}$ and Nobuaki Shime ${ }^{3}$
}

\begin{abstract}
Background: Early dumping syndrome characterized by palpitation, dizziness, cold sweat, feebleness, and abdominal symptoms, occurs within 30 minutes after meals in patients who have undergone gastrectomy. This case report describes the case of a patient who presented with severe distributive shock due to early dumping syndrome; he recovered within a few hours after massive fluid infusion and vasopressor administration.
\end{abstract}

Case presentation: Our patient was a 68-year-old Japanese man who underwent total gastrectomy for gastric cancer and was diagnosed as having late dumping syndrome. On admission, he developed severe shock and was treated with massive fluid administration. Based on the history of the present illness, past medical history, normal findings of blood chemistry test, transient course, and Sigtad score, which helps diagnose dumping syndrome, early dumping syndrome was considered the cause of severe distributive shock.

Conclusions: Early dumping syndrome can cause severe shock requiring massive fluid infusion and vasopressor administration. It should be considered a cause of severe distributive shock in patients who have undergone gastrectomy.

Keywords: Early dumping syndrome, Gastrectomy, Hypotension, Hyperlactatemia, Norepinephrine

\section{Background}

Early dumping syndrome occurs within 30 minutes after meals in patients who have undergone gastrectomy. It is characterized by palpitation, dizziness, cold sweat, feebleness, and abdominal symptoms, all of which are due to hypotension [1-4]. However, there are no reports about severe hypotension requiring massive infusion and vasopressor administration. Here, we report the case of a patient who presented with severe distributive shock due to early dumping syndrome and recovered within a few hours after massive fluid infusion and vasopressor administration.

\section{Case presentation}

A 68-year-old Japanese man, who had a history of total gastrectomy for gastric cancer and transcatheter arterial embolization for left adrenal gland aneurysm rupture, had been transported to our emergency department by

\footnotetext{
* Correspondence: t-k-s-t@koto.kpu-m.ac.jp

${ }^{1}$ Department of Intensive Care Medicine, Osaka Prefectural Hospital Organization, Osaka Women's and Children's Hospital, 840 Murodo-cho, Izumi, Osaka 594-1101, Japan

Full list of author information is available at the end of the article
}

ambulance several times. He had a history of repeated hypoglycemia after meals, leading to a diagnosis of late dumping syndrome. Prior to the most recent admission, he had abdominal pain followed by diarrhea after breakfast at approximately 8:30 a.m. He was found unconscious sitting on the toilet seat at approximately 9:00 p.m. and was transported to our emergency department 20 minutes later.

On arriving at our hospital, he was unable to describe his symptoms. His vital signs were as follows: Glasgow Coma Scale score, E3V4M6; respiratory rate, 30 breaths/ minute; oxygen saturation, $99 \%$ under room air; blood pressure, 60/28 $\mathrm{mmHg}$; heart rate, 90 beats/minute; and body temperature, $36.1{ }^{\circ} \mathrm{C}$. Arterial blood gas analysis revealed metabolic acidosis with respiratory compensation, hyperglycemia, and hyperlactatemia (Table 1). Blood biochemistry findings were within the normal limits (Table 2). After rapid administration of $2000 \mathrm{~mL}$ of bicarbonate Ringer's solution, his systolic blood pressure transiently increased to $100 \mathrm{mmHg}$, but this increase was not sustained. A chest radiograph and computed tomography images of his brain and whole body revealed no abnormal findings. Ultrasonography revealed normal

(c) The Author(s). 2018 Open Access This article is distributed under the terms of the Creative Commons Attribution 4.0 International License (http://creativecommons.org/licenses/by/4.0/), which permits unrestricted use, distribution, and reproduction in any medium, provided you give appropriate credit to the original author(s) and the source, provide a link to the Creative Commons license, and indicate if changes were made. The Creative Commons Public Domain Dedication waiver (http://creativecommons.org/publicdomain/zero/1.0/) applies to the data made available in this article, unless otherwise stated. 
Table 1 Arterial blood gas analysis (fraction of inspired oxygen: room air)

\begin{tabular}{lll}
\hline $\mathrm{PaO}_{2}$ & 110 & Torr \\
$\mathrm{PaCO}_{2}$ & 15.8 & Torr \\
$\mathrm{HCO}_{3}{ }^{-}$ & 8.4 & $\mathrm{mEq} / \mathrm{L}$ \\
$\mathrm{BE}$ & -15.7 & $\mathrm{mEq} / \mathrm{L}$ \\
$\mathrm{pH}$ & 7.344 & \\
$\mathrm{BS}$ & 289 & $\mathrm{mg} / \mathrm{dL}$ \\
$\mathrm{LaC}$ & 10.6 & $\mathrm{mmol} / \mathrm{L}$ \\
\hline
\end{tabular}

$\mathrm{BE}$ base excess, $\mathrm{BS}$ blood sugar, $\mathrm{HCO}_{3}{ }^{-}$bicarbonate ion, $\mathrm{Lac}$ lactate, $\mathrm{PaO}_{2}$ partial pressure of oxygen in arterial blood, $\mathrm{PaCO}_{2}$ partial pressure of carbon dioxide in arterial blood

contractility of his heart and collapse of the inferior vena cava. He was transferred to our intensive care unit (ICU) with further administration of bicarbonate Ringer's solution.

In the ICU, his lactate was decreased to $7.4 \mathrm{mmol} / \mathrm{L}$, while the hypotension persisted. A central venous catheter was inserted into the right internal jugular vein, and continuous infusion of noradrenaline was started and increased to $0.13 \mu \mathrm{g} / \mathrm{kg}$ per minute. Antibiotics were not administered as neither blood chemistry nor imaging revealed any findings of infection. As his hemodynamics gradually stabilized, after $3500 \mathrm{~mL}$ of fluid administration, continuous infusion of noradrenaline was stopped 4 hours after the initial infusion. He was able to eat supper on the same day and was discharged from the ICU on the following day. During admission, the plasma cortisol level was found to be normal; therefore, no steroids were administered.

\section{Discussion and conclusions}

To the best of our knowledge, this is the first report to describe severe distributive shock due to early dumping syndrome treated with massive infusion and vasopressor administration.

The pathogenesis of early dumping syndrome is as follows [1-7]. First, after gastrectomy, foods directly flush into the small intestine, causing sudden increases in

Table 2 Blood biochemistry findings

\begin{tabular}{llllll}
\hline TP & 7.1 & $\mathrm{~g} / \mathrm{dL}$ & $\mathrm{Na}$ & 140 & $\mathrm{mEq} / \mathrm{L}$ \\
Alb & 3.8 & $\mathrm{~g} / \mathrm{dL}$ & $\mathrm{K}$ & 3.0 & $\mathrm{mEq} / \mathrm{L}$ \\
CRP & 0.02 & $\mathrm{mg} / \mathrm{dL}$ & $\mathrm{Cl}$ & 103 & $\mathrm{mEq} / \mathrm{L}$ \\
PCT & 0.053 & $\mathrm{ng} / \mathrm{mL}$ & $\mathrm{WBC}$ & 4600 & $/ \mu \mathrm{L}$ \\
BUN & 13 & $\mathrm{mg} / \mathrm{dL}$ & $\mathrm{Hb}$ & 12 & $\mathrm{~g} / \mathrm{dL}$ \\
CRE & 1.17 & $\mathrm{mg} / \mathrm{dL}$ & $\mathrm{Hct}$ & 37.9 & $\%$ \\
Glu & 286 & $\mathrm{mg} / \mathrm{dL}$ & PLT & 19.4 & $10^{4} / \mu \mathrm{L}$ \\
\hline
\end{tabular}

Alb albumin, $B U N$ blood urea nitrogen, $C l$ chloride, CRP C-reactive protein, CRE creatinine, Glu glucose, $\mathrm{Hb}$ hemoglobin, $\mathrm{Hct}$ hematocrit, $\mathrm{K}$ potassium, $\mathrm{Na}$ sodium, PCT procalcitonin, PLT platelet, TP total protein, WBC white blood cell osmotic pressure in the small intestine, followed by shifting of fluids from the extracellular spaces to the intestinal lumen. Second, excessive secretion of gastrointestinal hormones (bradykinin, serotonin) cause splanchnic vasodilatation. Together, these two components could cause distributive shock. Severe hypotension requires massive fluid loading with noradrenaline to stabilize hemodynamics. In this patient, there was no evidence suggesting other causes of distributive shock including septic origin, which further supported our hypothesis. The presence of abdominal symptoms (abdominal pain and diarrhea) also contributed to the diagnosis of early dumping syndrome, as well as the severe shock manifestation.

Patients who have late dumping syndrome are often revealed to have early dumping syndrome as well [8]. In our case, our patient's history of total gastrectomy and late dumping syndrome, as well as his high Sigtad score $(>7)$ [3], which is used to diagnose dumping syndrome, also supported the diagnosis of early dumping syndrome.

Early dumping syndrome can cause severe shock that requires massive fluid infusion and vasopressor administration. It should be considered one of the causes of severe distributive shock in patients with a history of gastrectomy.

\section{Abbreviations}

ICU: Intensive care unit

\section{Acknowledgements}

We thank Editage (www.editage.jp) for English language editing.

\section{Funding}

This research did not receive any specific grant from funding agencies in the public, commercial, or not-for-profit sectors.

Availability of data and materials

Data sharing is not applicable to this article as no datasets were generated or analyzed during the current study.

\section{Authors' contributions}

$\mathrm{JT}$ performed the analysis on all samples, interpreted the data, wrote the manuscript, and acted as corresponding author. KN and NSh performed the analysis on all samples, interpreted the data, and wrote the manuscript. SB and NSa helped in data interpretation and supervised the manuscript drafting process. All authors read and approved the final manuscript.

\section{Ethics approval and consent to participate} NA.

\section{Consent for publication}

Written informed consent was obtained from the patient for publication of this case report and accompanying images. A copy of the written consent is available for review by the Editor-in-Chief of this journal.

\section{Competing interests}

The authors declare that they have no competing interests.

\section{Publisher's Note}

Springer Nature remains neutral with regard to jurisdictional claims in published maps and institutional affiliations.

\section{Author details}

${ }^{1}$ Department of Intensive Care Medicine, Osaka Prefectural Hospital

Organization, Osaka Women's and Children's Hospital, 840 Murodo-cho, 
Izumi, Osaka 594-1101, Japan. ${ }^{2}$ Department of Emergency and Critical Care Medicine, National Hospital Organization, Kyoto Medical Center, 1-1

Fukakusa, Mukaihata-cho, Fushimi-ku, Kyoto 612-8555, Japan. ${ }^{3}$ Department of Emergency and Critical Care Medicine, Institute of Biomedical \& Health

Sciences, Hiroshima University, 1-2-3 Kasumi, Minami-ku, Hiroshima 734-8551, Japan.

Received: 17 April 2018 Accepted: 13 August 2018

Published online: 13 September 2018

\section{References}

1. Mala T, Hewitt S, Hogestol IK, Kjellevold K, Kristinsson JA, Risstad H.

Dumping syndrome following gastric surgery. Tidsskr Nor Laegeforen. 2015; 135:137-41.

2. Johnson LP, Sloop RD, Jesseph JE. Etiologic significance of the early symptomatic phase in the dumping syndrome. Ann Surg. 1962;156:173-9.

3. Berg P, McCallum R. Dumping syndrome: a review of the current concepts of pathophysiology, diagnosis, and treatment. Dig Dis Sci. 2016;61:11-8.

4. Chaves YD, Destefani AC. Pathophysiology, diagnosis and treatment of dumping syndrome and its relation to bariatric surgery. Arq Bras Cir Dig. 2016;29(Suppl 1):116-9.

5. Vecht J, Masclee AA, Lamers CB. The dumping syndrome. Current insights into pathophysiology, diagnosis and treatment. Scand I Gastroenterol Suppl. 1997;223:21-7.

6. Tack J, Arts J, Caenepeel P, De Wulf D, Bisschops R. Pathophysiology, diagnosis and management of postoperative dumping syndrome. Nat Rev Gastroenterol Hepatol. 2009;6:583-90.

7. Lawrence W Jr, Mathews DH. A study of water shifts in experimental dumping syndrome. Surg Forum. 1960;10:180-5.

8. Eagon JC, Miedema BW, Kelly KA. Postgastrectomy syndromes. Surg Clin North Am. 1992;72:445-65.

Ready to submit your research? Choose BMC and benefit from:

- fast, convenient online submission

- thorough peer review by experienced researchers in your field

- rapid publication on acceptance

- support for research data, including large and complex data types

- gold Open Access which fosters wider collaboration and increased citations

- maximum visibility for your research: over $100 \mathrm{M}$ website views per year

At $\mathrm{BMC}$, research is always in progress.

Learn more biomedcentral.com/submissions 